\title{
PENGUATAN PARTISIPASI MASYARAKAT MELALUI PEMBANGUNAN
}

\author{
Dzul Fikri ${ }^{1}$, Ida Ardila Safitri Rumain ${ }^{2}$, Wulandari ${ }^{3}$, Selaswati ${ }^{2}$, Ade Erlin Tasari ${ }^{4}$, \\ Asep Abdu Renhoat ${ }^{2}$, Muhammad Masrani ${ }^{1}$, M. Zain Ainur Roat ${ }^{2}$, Hartono ${ }^{5}$, Achmad \\ Hamseh $^{3}$, M. Ata Saiful Mila ${ }^{3}$ \\ ${ }^{1}$ Fakultas Keguruan dan Ilmu Pendidikan, Universitas Islam Malang \\ ${ }^{2}$ Fakultas Ekonomi dan Bisnis, Universitas Islam Malang \\ ${ }^{3}$ Fakultas Agama Islam, Universitas Islam Malang \\ ${ }^{4}$ Fakultas Peternakan, Universitas Islam Malang \\ ${ }^{5}$ Fakultas Pertanian, Universitas Islam Malang \\ Korespondensi email: dzulfik@unisma.ac.id
}

\begin{abstract}
ABSTRAK
Di Kecamatan Ampelgading Kabupaten Malang Kelurahan Simojayan, partisispasi masyarakat cenderung masih belum secara keseluruhan. Undang-undang No. 6 Tahun 2014 mengamanatkan bahwa perencanaan pembangunan desa harus dilaksanakan secara partisipatif dan melibatkan seluruh masyarakat, termasuk kelompok rentan (minoritas, difabel, perempuan, dan miskin). Hal tersebut bertujuan agar pembangunan yang dilaksanakan oleh desa benar-benar bermanfaat bagi seluruh warga. Akan tetapi, hingga saat ini sebagian besar desa di Indonesia belum dapat melaksanakan amanat undangundang tersebut. Hal ini terbukti dengan masih adanya desa yang melaksanakan perencanaan pembangunan secara elitis dan sepenuhnya dilakukan oleh pemerintah desa tanpa melibatkan masyarakat. Selain itu, ada pula desa yang sudah mencoba melibatkan masyarakat yakni melalui proses pembangunan, namun belum semua komponen masyarakat diundang dalam proses tersebut tersebut. Dampak dari perencanaan pembangunan yang belum bersifat partisipatif adalah manfaat pembangunan desa belum bisa dirasakan oleh seluruh lapisan masyarakat, sehingga program pembangunan belum dapat disebut berhasil. Sebagai salah satu upaya untuk mewujudkan perencanaan pembangunan desa yang partisipatif, mahasiswa KKN-PPM TEMATIK UNIVERSITAS ISLAM MALANG mengadakan kegiatan pembangunan desa melalui proyek-proyek yang diusung di Desa Simojayan. Kegiatan tersebut melibatkan perwakilan dari semua komponen masyarakat desa (warga masyarakat, pengurus organisasi sosial, dan pemerintah desa). Melalui proses pembangunan desa diharapkan akan dapat dilaksanakan secara partisipatif di masa yang akan datang, sehingga hasil-hasil pembangunan dapat dirasakan oleh seluruh warga.
\end{abstract}

Kata Kunci: partisipasi; masyarakat; pembangunan desa.

\section{PENDAHULUAN}

Desa Simojayan adalah sebuah Desa diwilayah Kecamatan Ampelgading dimana Kecamatan Ampelgading merupakan Kecamatan yang terletak di wilayah Kabupaten Malang Kecamatan ini terdiri dari 13 Desa, 39 Dusun/Dukuh, 97 RW dan 317 RT. Ke-13 Desa di kecamatan ini adalah Argoyuwono, Lebakharjo, Mulyosari, Purwoharjo, Sidorenggo, Tamanasri, Tamansari, Tawangagung, Tirtomarto, Tirtomoyo, Wirotaman, Sonowangi dan Simojayan dimana salah satu desa yang dipilih sebagai Lokasi KKN untuk 
kami mengabdi selama satu bulan sebagai perwujudan kegiatan Tri Dharma Perguruan Tinggi. Membawa misi menciptakan pengabdian masyarakat dengan orientasi pengembangan potensi wilayah, KKN PPM TEMATIK KELOMPOK 26 UNIVERSITAS ISLAM MALANG di Desa Simojayan Kecamatan Ampelgading telah melakukan Pembangunan Desa melalui program kerja dalam bentuk proyek-proyek yang diusung guna untuk membantu pembangunan Desa.

Pembangunan sering diartikan sebagai pemenuhan kebutuhan fasilitas dan infrastruktur fisik yang didatangkan dari luar, dilaksanakan dengan peran pemerintah yang sangat dominan, dan dengan perencanaan dari atas (top down) (Warsilan \& Noor, 2015). Demikian pula dengan pembangunan desa dan perdesaan. meski ada upaya untuk menerapkan model-model perencanaan dari bawah (bottom up). Namun masih sangat terbatas, karena orientasi pembangunan lebih pada pengadaan dan penyediaan infrastruktur fisik, maka pembangunan dengan orientasi nonfisik seperti kebersaman, kegotong-royongan, kekeluargaan, musyawarah, demokrasi, kemandirian, dan partisipasi menjadi terabaikan (Ratnadila, 2018).

Satu Pengalaman empirik menunjukkan bahwa dalam pendekatan pembangunan desa yang dilakukan selama ini masih bersifat top down, artinya peran pemerintah masih dominan dalam pelaksanaan pembangunan desa dibandingkan dengan partisipasi masyarakat baik pada tataran perencanaan maupun pelaksanaan (Imtihan et al., 2017) (Kader \& Radjak, 2020). Akibatnya, seringkali kegiatan pembangunan desa belum mencerminkan kebutuhan masyarakat. Sementara itu, perguruan tinggi diketahui telah memiliki instrumen kelembagaan yang secara langsung berkaitan dengan intervensi terhadap masyarakat yaitu Program Kerja Kuliah Kerja Nyata (KKN).

KKN sejatinya merupakan salah satu dari pelaksanaan Tridharma Perguruan Tinggi yaitu pengabdian kepada masyarakat. Dalam rangka meningkatkan pembangunan desa dikembangkan model Kuliah Kerja Nyata (KKN) Mahasiswa Membangun Desa, yaitu sebuah pendekatan intervensi sosial yang lebih menekankan pada aspek 'proses'. KKN tidak dapat dilihat langsung hasilnya pada saat ini dengan anggapan pengaruh KKN akan dapat dilihat pada jangka panjang baik peningkatakan kapasitas desa maupun sumber daya manusia (regenerasi) yang memahami konteks perdesaan (Syardiansah, 2019).

KKN-PPM Tematik Kelompok 26 dengan tema "Penguatan Partisipasi Masyarakat melalui Pembangunan" diselenggarakan dalam rangka mendampingi masyarakat membangun desanya secara aktif. Mahasiswa yang mengikuti KKN ini diharapkan dapat memprakondisikan masyarakat desa untuk berpikir kritis tentang masalah di desanya, dan bersama-sama menemukan gagasan-gagasan kreatif untuk memecahkannya. KKN TematikPPM Universitas Islam Malang menuntut keterlibatan aktif mahasiswa dalam berdialog secara intensif dengan masyarakat. KKN-PPM Tematik berorientasi pada alih pengetahuan model Kuliah Kerja Nyata Pembelajaran Pemberdayaan Masyarakat Tematik Pembangunan desa (transfer knowledge) arah baik kepada masyarakat maupun mahasiswa, serta pembelajaran pengabdian kepada masyarakat (Danial et al., 2019).

Masalah dalam kegiatan pengabdian kepada masyarakat yang dilaksanakan di Desa Simojayan ini adalah: (1) Bagaimana cara meningkatkan kesadaran Masyarakat Simojayan dalam berpartisipasi terhadap Proses pembangunan Desa? (2) Bagaimana cara meningkatkan Kesadaran Organisasi sosial Kemasyarakatan, Organisasi Keagamaan, dan Intitusi Sosial Desa Somojayan dalam proses pembangun Desa?

Tujuan dalam kegiatan pengabdian kepada masyarakat yang dilaksanakan di Desa Simojayan ini sebagai berikut: (1) Meningkatnya kesadaran warga masyarakat, termasuk kelompok rentan untuk ikut berpatisipasi dalam proses pembangunan desa sehingga hasil pembangunan tersebut benar-benar mencerminkan prinsip partisipatif, yaitu melibatkan 
seluruh warga masyarakat; (2) Meningkatnya kesadaran organisasi sosial kemasyarakatan (PKK, karang taruna, kelompok tani, P3A, dasawisma, dll), organisasi sosial keagamaan (majelis taklim, TPA, kelompok pengajian, dll.), dan institusi/pranata sosial (rembuk warga, pertemuan RT/RW, gotong royong, dll.) yang ada di Desa Simojayan untuk menjadi ajang pengorganisasian dalam membangun desa.

Menurut hasil penelitian Agustin \& Rahaju (2016), keberhasilan suatu program pembangunan bukan hanya berdasar pada kemampuan pemerintah, tetapi juga berkaitan dengan partisipasi masyarakat dalam menjalankan program pembangunan. Hal tersebut selaras dengan hasil penelitian yang telah dilakukan oleh Susetiawan et al. (2018) bahwa partisipasi masyarakat dalam pembangunan sangat berpengaruh pada keberhasilan pelaksanaan suatu program pembangunan. Menurut Hardianti et al. (2017), partisipasi masyarakat dalam pembangunan sangat penting karena partisipasi/keikutsertaan masyarakat tersebut akan menumbuhkan rasa memiliki terhadap proses pembangunan khususnya pelaksanaan program pembangunan di desa. Menurut Fadil (2013) partisipasi masyarakat dapat didefenisikan sebagai keterlibatan dan pelibatan anggota masyarakat dalam pembangunan, meliputi kegiatan dalam perencanaan dan pelaksanaan (implementasi) program pembangunan. Peningkatan partisipasi masyarakat merupakan salah satu bentuk pemberdayaan masyarakat (social empowerment) secara aktif yang berorentasi pada pencapaian hasil pembangunan yang dilakukan dalam masyarakat pedesaan. Pemberdayaan masyarakat merupakan upaya pemanfaatan dan pengelolaan sumber daya masyarakat pedesaan secara lebih aktif dan efisien (Martino et al., 2018).

Susetiawan et al. (2018) mendefinisikan partisipasi sebagai kemauan rakyat untuk mendukung secara mutlak program-program pemerintah yang ditentukan dan tujuannya oleh pemerintah. Dia juga menambahkan bahwa partisipasi adalah kerja sama antara rakyat dan pemerintah dalam merencanakan, melaksanakan, melestarikan, dan mengembangkan hasil pembangunan. Sementara itu, Laily, (2015) mendefinisikan partisipasi sebagai kesediaan untuk membantu keberhasilan setiap program sesuai dengan kemampuan setiap orang tanpa berarti mengorbankan kepentingan diri sendiri. Ulum \& Ngindana (2017) mendefinisikan partisipasi sebagai feedforward information and feedback information. Dengan definisi ini, partisipasi masyarakat sebagai proses komunikasi dua arah yang terus menerus dapat diartikan sebagai komunikasi antara pihak pemerintah sebagai pemegang kebijakan dan masyarakat di sisi lain sebagai pihak yang merasakan langsung dampak dari kebijakan tersebut.

Desa menurut UU No. 6 tahun 2014 adalah kesatuan masyarakat hukum yang memiliki batas wilayah yang berwenang untuk mengatur dan mengurus urusan pemerintahan, kepentingan masyarakat setempat berdasarkan prakarsa masyarakat, hak asal usul, dan atau hak tradisional yang diakui dan dihormati dalam sistem pemerintahan Negara Kesatuan Republik Indonesia. Untuk mendapatkan dukungan dan partisipasi yang kuat dari masyarakat terhadap pembangunan desa, maka masyarakat harus dilibatkan dalam proses pengambilan keputusan termasuk pada tahapan perencanaan pembangunan desa. Dengan demikian diharapkan akan timbul suatu rasa tanggung jawab bersama seluruh masyarakat desa terhadap pembangunan di desanya. Namun, untuk bisa berpartisipasi dalam pembangunan, menurut Maripah \& Sujianto (2017) masyarakat perlu memiliki pemahaman yang luas tentang pembangunan partisipatif, khususnya dalam aspek perencanaan. Pemahaman masyarakat terhadap partisipasi dalam perencanaan sangat diperlukan dalam pembangunan partisipatif karena pemahaman terhadap perencanaan dalam pembangunan partisipatif akan menimbulkan suatu kesadaran masyarakat betapa pentingnya partisipasi masyarakat. 
Kesejahteraan sosial dalam Islam pada intinya mencakup dua hal pokok yaitu kesejahteraan sosial yang bersifat jasmani (lahir) dan rohani (batin). Sejahtera lahir dan batin tersebut harus terwujud dalam setiap pribadi (individu) yang bekerja untuk kesejahteraan hidupnya sendiri, sehingga akan terbentuk keluarga/masyarakat dan negeri yang sejahtera. Mengingat luasnya definisi kesejahteraan dan banyaknya ayat-ayat Al-Quran yang berkaitan, maka bahasan kesejahteraan akan dibatasi "lebih kepada aspek ekonomi". Demikian pula ayat-ayat Al-Quran yang terkait secara langsung dengan konsep kesejahteraan dibatasi pada usaha/bekerja, sebagai titik tolak pemilihan ayat yang akan dibahas. Adapun ayat yang akan dipergunakan untuk memperdalam pembahasan akan dipilih beberapa ayat yang berkaitan, yakni: Ayat yang dipilih adalah QS. Al-Taubah/9:105 yang artinya Dan Katakanlah: "Bekerjalah kamu, Maka Allah dan Rasul-Nya serta orangorang mukmin akan melihat pekerjaanmu itu, dan kamu akan dikembalikan kepada (Allah) yang mengetahui akan yang ghaib dan yang nyata, lalu diberitakan-Nya kepada kamu apa yang telah kamu kerjakan".

Penjelasan dari Al-taubah ayat 105 adalah bahwa manusia haruslah selalu mensyukuri atas nikmat yang telah diberikan oleh Allah SWT dan tetap bekerja keras demi kesejahtraan hidup baik individu maupun sosial Tentunya nikmat tersebut senantiasa kita jaga kita rawat dan kita lestarikan agar kelak nanti anak cucu kita masih dapat menikmati atas apa yang telah diberikan-Nya. Serta merencanakan pembangunan tata ruang yang tidak merugikan masyarakat, berharap pembangunan desa mengarah pada kesejahtraan masyarakat terutama pada masyarakat lapisan bawah. Terkadang kebijakan Pembangunan tata ruang yang tidak didasari dengan hati nurani dan tidak berpedoman pada ajaran Islam kedepannya akan menimbulkan suatu permasalahan yang lebih besar, sudah banyak kasus-kasus Tata Ruang kota yang perencanaannya tidak berpedoman pada nilai-nilai islam, akhirnya yang terjadi adalah kerusakan, dan bencana. Hal ini seakan memberikan isyarat bahwa bekerja yang sungguh-sungguh itu akan memberi manfaat tidak hanya untuk dirinya, namun untuk kaum muslimin (masyarakat atau bahkan negara), tidak hanya bermanfaat di dunia namun juga bermanfaat untuk kehidupan akhirat, dan orang yang menerima manfaat tersebut akan menilai dan menjadi saksi di akhirat,kesaksian yang diperkuat oleh kesaksian Rasul SAW dan kesaksian dari Yang Maha Mengetahui yang gaib dan nyata (Allah SWT). Selanjutnya untuk menggali isyarat makna bekerja yang dilakukan pada ranah individu, keluarga/masyarakt dan negara akan menggunakan keterangan yang ada pada ayat lain (ayat pilihan), menggunakan hadist Rasulullah SAW.

NU yang berbasis di pedesaan sedikit banyak tentu terdampak dengan keadaan tersebut. Tidak dipungkiri, peran NU sangat besar dalam mengawal kehidupan berbangsa dan bernegara. NU telah menjadi garda terdepan terhadap berbagai persoalan bangsa. Namun, peran NU dicemaskan tergerus seiring melemahnya soliditas dan daya tahan NU akibat kemiskinan struktural massa NU di pedesaan. Masa reformasi pun bergulir. Otonomi Daerah menjadi bagian penting agenda reformasi. Dalam perkembangannya, terbitlah Undang-Undang Nomor 6 Tahun 2014 tentang Desa. Undang-undang tersebut mengamanahkan paradigma baru dalam membangun desa sebagai bagian penting pembangunan nasional. Setelah berpuluh tahun dipunggungi, akhirnya desa mendapat penguatan yuridis. Hal itu pun dipertegas dengan Nawa Cita Presiden Jokowi, yakni membangun Indonesia dari pinggiran. Gerakan dan partisipasi masyarakat juga harus terbangun dengan baik.

Menurut Sigalingging \& Warjio (2014), ada tiga alasan utama mengapa partisipasi masyarakat mempunyai sifat sangat penting. Pertama, partisipasi masyarakat merupakan suatu alat guna memperoleh informasi mengenai kondisi, kebutuhan dan sikap masyarakat setempat, yang tanpa kehadirannya program pembangunan serta proyek-proyek akan 
gagal. Kedua, masyarakat akan lebih mempercayai proyek atau program pembangunan jika merasa dilibatkan dalam proses persiapan dan perencanaannya, karena mereka akan lebih mengetahui seluk beluk proyek tersebut dan akan mempunyai rasa memiliki terhadap proyek tersebut. Ketiga, timbul anggapan bahwa merupakan suatu hak demokrasi bila masyarakat dilibatkan dalam pembangunan masyarakat mereka sendiri. Dapat dirasakan bahwa merekapun mempunyai hak untuk turut memberikan saran dalam menentukan jenis pembangunan yang akan dilaksanakan. Hal ini selaras dengan konsep man-centred development (suatu pembangunan yang dipusatkan pada kepentingan manusia), yaitu jenis pembangunan yang lebih diarahkan demi perbaikan nasib manusia dan tidak sekedar sebagai alat pembangunan itu sendiri. Peningkatan partisipasi masyarakat dalam proses pengambilan keputusan yang menyangkut diri dan masyarakatnya merupakan unsur yang sungguh penting dalam pemberdayaan masyarakat. Dengan dasar pandang demikian, maka pemberdayaan masyarakat amat erat kaitannya dengan pemantapan, pembudayaan, dan pengamalan demokrasi.

\section{METODE}

Metode yang digunakan dalam membangun desa ini adalah metode ZOPP (Ziel, Oriented, Projekt, dan Planning). Metode ini secara resmi diperkenelkan oleh Gesellschaft fur tecnhnische zusam menarbeit pada tahun 1983 di Jerman dan metode ini merupakan sebuah perencanan proyek yang berorientasi kepada tujuan. Dengan metode ini, maka masyarakat sasaran diperlakukan sebagai subjek dan objek dalam kegiatan pembangunan desa (Fahmie, 2001). Dalam metode ZOPP ini digunakan untuk meningkatkan peran melalui partisipatif masyarakat dapat dikaji keadaan desa dengan empat alat kajian yaitu: kajian permasalahan, kajian tujuan, kajian alternatif (pilihan-pilihan) dan kajian peran.

1. Kajian Permasalahan

Dimaksudkan untuk menyidik masalah-masalah yang terkait dengan suatu keadaan yang ingin diperbaiki melalui suatu proyek pembangunan.

2. Kajian Tujuan

Untuk meneliti tujuan-tujuan yang dapat dicapai sebagai akibat dari pemecahan masalah-masalah tersebut.

3. Kajian Alternatif (pilihan-pilihan)

Untuk menetapkan pendekatan proyek yang paling memberi harapan untuk berhasil.

4. Kajian Peran

Untuk mendata berbagai pihak (lembaga, kelompok masyarakat dan sebagainya) yang berkaitan dengan proyek selanjutnya mengkaji kepentingan dan potensi.

Perencanaan dengan metode ZOPP mempuyai kegunaan untuk meningkatkan kerjasama semua pihak yang terkait, mengetahui keadaan yang ingin diperbaiki melalui proyek, merumuskan tindakan-tindakan yang diperlukan untuk mencapai tujuan yang diinginkan dan sebagai dasar pelaksanaan proyek. Mutu hasil dari perencanaan itu sangat tergantung pada informasi yang tersedia dan yang diberikan

\section{HASIL DAN PEMBAHASAN}

Dalam kurun waktu satu bulan masa pelaksanaan kegiatan pengabdian masyarakat, KKN-PPM TEMATIK Kelompok 26 Univertas Islam Malang telah melaksanakan kegiatan pengabdian dalam membangun desa melalui Proses Pembangunan dari Proyek-Proyek yang disusun yakni : bedah rumah, renovasi taman, menghias lapangan TK, renovasi TPQ dan Masjid, melabeli TPQ dan mushola, melabelisasi logo NU di mushola baiturrahman, tahlil rutinan, silaturahmi kerumah warga, mengadakan bimbingan belajar pada anak sekolah TK dan SD di Desa simojayan, berdasarkan uraian dari proyek-proyek yang telah 
disajikan diatas telah menggambarkan bahwa pembangunan desa disini bukan hanya pada wilayah infrastruktur namun juga pada partisipasi bersama masyarakat dalam menjaga silahturahmi juga turut membantu dalam hal pendidikan di Desa Simojayan. Sehingga proyek-proyek yang akan dilaksanakan dalam proses pembangunan desa baik infrastruktuk fisik maupun nonfisik akan berdampak pada partisipasi masyarakat simojayan dalam membangun desa di pedesaan. Untuk lebih jelas akan di paparkan tahapan pelaksanan proyek-proyek terkait pembangunan desa yaitu:

\section{Bedah Rumah}

Bedah rumah merupakan kegiatan yang dilakukan dalam rangka perbaikan rumah tidak layak huni, yaitu rumah tempat tinggal yang tidak memenuhi syarat kesehatan, keamanan dan sosial. Rehabilitasi dimaksudkan sebagai upaya memperbaiki kondisi rumah baik secara menyeluruh maupun sebagian atau renovasi sehingga tercipta kondisi rumah yang layak sebagai tempat tinggal. Dalam operasional kegiatan Pelaksanaan bedah rumah di Desa Simojayan dilakukan secara bergotongroyong bersama-sama masyarakat membangun, memperbaiki rumah yang dikerjakan yang dilaksanakan oleh Pemerintah desa dengan melibatkan partisipasi dari mahasiswa KKN-PPM tematik unisma dengan beberapa elemen masyarakat yang berada didekat lokasi mitra rumah yang dibedah. Pelaksanaan bedah rumah dipadukan dengan pembangunan sarana lingkungan untuk mendukung tempat tinggal atau hunian yang sehat dalam rangka menanggulangi kemiskinan pedesaan Hal ini selaras dengan amanat Undang-undang Nomor 13 Tahun 2011 tentang Penanganan Fakir Miskin. Penanganan fakir miskin dilakukan secara sinergi dan terpadu, program meliputi rehabilitasi, jaminan sosial,perlindungan dan pemberdayaan. Salah satu solusi penanganan kemiskinan adalah melalui program bedah rumah yang merupakan kegiatan rehabilitasi sosial rumah tidak layak huni (RTLH).

Undang undang Nomor 1 tahun 2011 tentang perumahan dan kawasan menegaskan, bahwa setiap warga negara mempunyai hak untuk memiliki rumah layak huni dalam lingkungan yang sehat, aman, serasi dan teratur. Hak konstitusi tersebut mestinya juga melekat pada mereka yang tergolong fakir miskin. Fakir miskin adalah orang yang sama sekali tidak mempunyai sumber mata pencaharian atau mempunyai pencaharian tetapi tidak mempunyai kemampuan memenuhi kebutuhan dasar yang layak bagi kehidupan diri dan keluarganya (Undang-undang Nomor 13 Tahun 2011).

\section{Renovasi Masjid dan Taman Pendidikan Al-Qur'an Nurul Hidayah}

Keberadaan Masjid dan Taman Pendidikan Al-Qur'an (TPQ) Nurul hidayah yang terletak di Desa Simojayan Kecamatan Ampelgading Kabupaten Malang. Masjid Nurul Hidayah adalah salah satu dari banyaknya Masjid-Masjid di Desa Simojayan yang merupakan Tempat Beribadah Umat Islam dan TPQ merupakan lembaga yang mengelola pendidikan keagamaan di wilayah tersebut. Atas inisiatif salah satu tokoh agama dan didukung oleh beberapa elemen masyarakat setempat muncul sebuah gagasan yang menginginkan agar TPQ serta Masjid dibongkar kemudian direnovasi agar menjadi tempat ibadah yang nyaman untuk anak-anak yang belajar membaca alQur'an di TPQ dan masyarakat yang melakukan ibadah di Masjid Nurul Hidayah. Dalam operasionalnya kegiatan renovasi ini dilakukan secara bergotong-royong dimana dapat melibatkan partisipasi dari mahasiswa KKN-PPM tematik unisma, anak-anak tpq nurul hidayah dan beberapa elemen masyarakat yang ada di dekat mitra lembaga tersebut. Jelas bahwa tempat ibadah umat Islam dan tembat belajar Al-qur'an anak-anak desa simojayan telah direnovasi dapat dipergunakan sebagai tempat yang nyaman Hal ini selaras dengan Peraturan Pemerintah No. 55 tahun 2007 pasal 24 ayat 2 tentang 
Pendidikan Agama dan Pendidikan Keagamaan menyatakan bahwa Pendidikan AlQur'an terdiri dari Taman Kanak-Kanak al-Qur'an (TKA/TKQ), Taman Pendidikan alQur'an (TPQ/TPQ), Ta'limul Qur'an lil Aulad (TQA), dan bentuk lainnya yang sejenis. Perkembangan lembaga pendidikan al-Qur'an yang begitu pesat menandakan makin meingkatnya kemampuan kesadaran masyarakat. akan pentingnya kemampuan baca tulis al-Qur'an dan keberadannya di Indonesia.

\section{Renovasi Taman Desa Simojayan}

Taman adalah kebun yang ditanami dengan bunga-bunga atau tanaman hias yang tertata rapi, berirama, harmonis, dan seimbang yang bertujuan sebagai tempat menanam tumbuh-tumbuhan dan bersantai. Renovasi Taman Desa merupakan bentuk kontribusi mahasiswa KKN-PPM tematik universitas islam malang kepada Desa Simojayan yang bekerja sama dengan aparat desa dengan tujuan untuk memperindah suasana desa kebetulan taman ini terletak diantara pertigaan jalan raya dekat kantor balai desa guna meningkatkan daya tarik masyarakat akan cinta lingkungan yang bersih dan indah jika di pandang masyarakat Desa Simojayan. Mahasiswa KKN merenovasi taman ini dengan beberapa cara yaitu membersihkan taman lalu menanam tanaman-tanaman seperti bunga-bungan agar indah, membuat nama simojayan dari beberapa tumbuhan sehingga terlaksanalah taman yang sudah direnovasi agar bisa digunakan sebagai tempat menjaga tumbuh-tumbuhan serta untuk bersantai hal ini selaras dengan pendapat Santoso 2010 bahwa fungsi tanaman hias dapat dirasakan oleh manusia sebagai mahluk individu dan masyarakat sebagai mahluk sosial terutama bidang lingkungan hal ini juga dikuatkan dari segi keagamaan melalui kajian objektif dalam Islam menjaga lingkungan alam termasuk menjaga ciptaan Allah, Allah kekuasaan menumbuhkan tanaman-tanaman yang indah yang terletak di gununggunung sesuai ayat Al-qur'an pada surah Qaaf (50):7 yang artinya "Dan kami hamparkan bumi itu dan kami letakkan padanya gunung-gunung yang kokoh dan kami tumbuhkan padanya segala macam tanaman yang indah dipandang mata".

\section{Menghias Halaman TK}

Halaman Sekolah merupakan salah satu tempat atau wahana yang paling umum digunakan sebagai media bermain anak-anak selain bermain juga untuk belajar. Atas inisiatif mahasiswa KKN-PPM tematik universitas islam malang kelompok 26 dengan gagasan untuk mewujudkan halaman yang indah dan nyaman agar anak-anak dapat bermain dan belajar dihalaman sekolah bekerjasama dengan mitra sekolah TK dengan aneka keindahan warna warni yang dihias dihalaman sekolah tersebut agar dapat menciptakan halaman yang indah dan nyaman dengan menarik daya tarik anak-anak agar mereka bersemangat bermain dan belajar. Hal ini selaras dengan pendapat Solehuddin (1997) mengatakan bahwa pendidikan pra sekolah yang diwujudkan sebagai Taman Kanak-kanak pada hakekatnya adalah tempat anak bermain sambil belajar atau belajar sambil bermain. Anak-anak TK masuk sekolah sebenarnya adalah untuk bermain dan mengenal lingkungan. Pemerintah Indonesia di bidang pendidikan pra sekolah juga menganut prinsip "bermain sambil belajar atau belajar seraya bermain". Oleh karena itu, kegiatan pembelajaran bagi murid TK semestinya dilakukan di dalam ruang kelas maupun di luar kelas atau halaman sekolah.

\section{Melabelisasi Logo NU Di Mushola Baiturrahman}

Melabelisasi Logo merupakan bagian dari penyampaian informasi atas maksud dan tujuan serta makna dari logo tersebut yang dilabelkan di Mushola baiturrahman 
guna memberikan informasi terkait logo yang dipasangkan di mushola tersebut karena melihat Desa Simojayan merupakan desa yang kental dengan adat serta tradisinya dimana tradisi budaya dari desa ini yang paling menonjol adalah budaya religiusnya. Simojayan menganut paham Nahdatul Ulama hal ini selaras dengan inisiatif mahasiswa agar dilabelkan logo tersebut di mushola yang direnovasi sebagai tanda bahwa desa tersebut menganut paham Nahdatul Ulama.

\section{Melabelisasi TPQ Nurul Hidayah}

Melabelisasi merupakan bagian dari penyampaian informasi dan sabagai indentitas. Melabelisasi yang dilakukan pada gedung TPQ Nurul Hidayah Desa Simojayan adalah bagian dinding gedung dicat dan disesain seindah mungkin agar menarik daya tarik anak-anak dalam proses belajar mengajar. Pada Kegiatan ini Mahasiswa dan Masyarakat berpartisipasi sebagai bentuk kerja sama yang dibangun guna menunjang proses pembangunan desa.

\section{Silaturahmi Ke Rumah Warga Masyarakat Simojayan}

Menyambung tali silaturahmi dengan manusia bisa menjadi cara kita untuk kembali terhubung dengan Sang Pecipta. Memperlakukan manusia dengan baik juga jadi salah satu cara menjalankan perintah-Nya. Menjaga kerukunan dan perdamaian dengan sesama merupakan salah satu cara kita untuk bisa dekat dengan Allah SWT. Pada kegiatan silaturahmi kami mencoba mempererat tali persaudaraan kami dengan warga simojayan dengan jalan berkunjung kerumah rumah warga disana kami membangun cara kami berkomunikasi dengan warga agar terciptanyanya komunikasi yang baik dan juga memperkuat ukhuwah islamiyah kita antar warga simojayan. Islam adalah agama yang mengandung makna kedamaian, keharmonisan, kerukunan, persaudaraan dan persatuan. hal tersebut terbukti, karena agama Islam mengajarkan ukhuwah Islamiyah atau persaudaraan islam, ajaran ini adalah salah satu aspek yang sangat ditekankan dalam kehidupan beragama. Di dalam Agama Islam banyak perintah dan anjuran untuk mempererat tali silaturahmi atau ikatan persaudaraan antara sesama umat islam dan didalam agama islam juga melarang untuk memutuskan tali silaturahmi atau persaudaraan. perintah mempererat tersebut bisa dilihat dari Firman Allah SWT dalam Surah An-nisa :1 yang artinya "Dan bertakwalah kepada Allah dengan mempergunakan nama-nama-Nya, kamu saling meminta dan periharalah hubungan silaturahmi". Firman Allah SWT dalam mempererat tali silaturahmi tersebut diperkuat dalam haidst Riwayat Bukhori dan Muslim, yang menggambarkan bahwa seseorang yang bertaat beragama Islam atau mukmin bagaikan satu bangunan yang saling memperkuat "seorang mukmin terhadap Mukmin (lainnya) bagaikan satu bangunan, satu sama lain saling menguatkan" (HR Bukhiri dan Muslim).

\section{Melakukan Bimbel Pada Anak-Anak Desa Simojayan}

Pendidikan berbasis masyarakat adalah penyelenggaraan pendidikan berdasarkan kekhasan agama, sosial, budaya, aspirasi, dan potensi masyarakat sebagai perwujudan pendidikan dari, oleh dan untuk masyarakat. UU No 20 Tahun 2003 tentang SISDIKNAS. Islam tidak membebaskan manusia dari tanggungjawabnya sebagai anggota masyarakat, dia merupakan bagian yang integral sehingga harus tunduk pada norma-norma yang berlaku dalam masyarakatnya. Begitu juga dengan tanggungjawabnya dalam melaksanakan tugas-tugas pendidikan. Sebagai bentuk tanggungjawab Mahasiswa terhadap masyarakat dan peduli terhadap pendidikan maka Mahasiswa KKN-PPM TEMATIK UNISMA kelompok 26 menyelenggarakan kegiatan 
bimbel (Binbingan Belajar) yang dikategorikan sebagai Lembaga Pendidikan Nonformal. Dalam kegiatan ini kami melibatkan masyarakat guna menunjang pendidikan diluar sekolah yang di agendakan setiap sore diluar jam sekolah bertempat dilokasi posko Mahasiswa KKN-PPM tematik unisma 2020, harapan yang sangat dalam dari mahasiswa KKN-PPM tematik unisma agar tetap terjalin interaksi antara mahasiswa dan masyarakat dalam mengembang pendidikan nonformal di Desa Simojayan juga sebagai bentuk kepedulian terhadap dalam mencerdaskan regegerasi bangsa hal ini senada dengan bunyi dari UUD 1945 Alinea Ke-4 yakni "Ikut Mencerdaskan Kehidupan Bangsa"

Proyek-Proyek yang telah diuraikan diatas dapat diterangkan bahwa pembangunan yang dilakukan oleh mahasiwa KKN-PPM tematik universitas islam malang dengan melibatkan elemen masyarakat simojayan dengan tujuan agar penguatan partisipasi dari masyarakat di tingkatkan sehingga akan berdampak pada partisipasi masyarakat di Desa Simojayan Kecamatan Ampelgading. Dengan kata lain jika Pembangunan sudah memadai maka dapat berpengaruh pada partisipasi yang sedang dikuatkan melalui pembangunan sehingga akan berdampak baik pada kesejahteraan Masyarakat Simojayan, karena telah membelibatkan masyarakat dalam pembangunan desa. Namun sebaliknya jika pembangunan belum memadai maka akan berpengaruh pada partisipasi masyarakat dalam hal pembangunan desa.

Ada beberapa indikator yang digunakan untuk melihat terjadinya peningkatan kesadaran warga masyarakat, pengurus organisasi, dan aparat pemerintah desa dalam pembangunan desa. Beberapa indikator tersebut sebagai berikut:

1. Terbangunnya komitmen warga masyarakat untuk berani melibatkan diri pada pembangunan desa.

2. Terbangunnya komitmen organisasi warga untuk mulai mempraktikkan dan mendiskusikan tata cara pembangunan dengan prosedur yang baik.

3. Terbangunnya komitmen aparat pemerintahan desa untuk terbuka, responsif, dan akuntabel dalam pembangunan desa.

Untuk mengukur tingkat keberhasilan kegiatan Pembangunan dalam membangun komitmen warga masyarakat, komitmen pengurus organisasi sosial warga, serta komitmen aparat pemerintahan desa dalam perencanaan proses pembangunan desa yang lebih partisipatif, setelah pelaksanaan kegiatan pembangunan diadakan survei terhadap warga masyarakat desa simojayan oleh mahasiswa KKN-PPM tematik itu sendiri. Pembangunan desa sebagaimana diamanahkan dalam Undang-Undang Nomor 6 tahun 2014 tentang Desa bertujuan untuk meningkatkan kesejahteraan masyarakat desa dan kualitas hidup manusia serta penanggulangan kemiskinan melalui pemenuhan kebutuhan dasar, pembangunan sarana dan prasarana desa, pengembangan potensi ekonomi lokal, serta pemanfaatan sumber daya alam dan lingkungan secara berkelanjutan (Dewi, 2020). Undang-undang desa tersebut mengamanahkan pembangunan desa dilaksanakan melalui dua pendekatan yaitu desa membangun dan membangun desa, yang keduanya diintegrasikan dalam perencanaan pembangunan desa.. Pendekatan pembangunan desa mengisyaratkan pentingnya peran pemerintah (top down) dalam pembangunan desa. Sementara pendekatan desa membangun mencerminkan adanya amanah memberi ruang yang lebih luas bagi masyarakat untuk berperan serta dalam pembangunan desa. Pembangunan desa meliputi tahap-tahap yang telah diuraikan diatas melalui proyek-proyek yang di laksanakan mahasiswa KKN-PPM tematik universitas islam malang. Aspek yang digarap dalam pembangunan desa distrukturkan ke dalam bidang penyelenggaraan pemerintahan 
Desa, pelaksanaan pembangunan Desa, pembinaan kemasyarakatan Desa dan pemberdayaan masyarakat Desa.

Dengan dinyatakannya pendekatan desa membangun dalam pembangunan desa sebagaimana dimaksud UU No. 6 Tahun 2014 memperlihatkan adanya cara pandang baru dalam pembangunan desa. Dalam pembangunan desa telah terjadi transformasi yang signifikan dalam penggunaan paradigma sebagai landasan kebijakan, pembangunan desa tidak lagi didominasi oleh peran pemerintah (top down). Cara pandang baru ini diperlihatkan dari asas pembangunan desa, meliputi rekognisi, subsidiaritas, keberagaman, kebersamaan, kegotong royongan, kekeluargaan, musyawarah, demokrasi, kemandirian, partisipasi, kesetaraan, pemberdayaan, serta keberlanjutan. Pendekatan desa membangun memberi ruang yang lebih luas untuk berjalannya partisipasi masyarakat pada tataran pembangunan. Dalam perspektif desa membangun, desa dipandang sebagai paduan antara entitas masyarakat desa yang kuat dan pemerintah desa yang kuat. Oleh karenanya peran aktif masyarakat dalam seluruh proses pembangunan sangat penting. Dengan demikian desa membangun berarti desa mempunyai kemandirian dalam membangun dirinya (self development). Dalam konteks desa membangun, membangun desa berarti Negara berdiri di belakang desa, atau tut wuri handayani (Eko, 2014).

\section{KESIMPULAN}

Dalam mempercepat pembangunan desa, perguruan tinggi memiliki programprogram yang langsung menyentuh masyarakat desa, terutama melalui program Kuliah Kerja Nyata (KKN) yang diikuti oleh mahasiswa. Bahkan pada sebagian perguruan tinggi, KKN menjadi mata kuliah wajib. Program KKN secara sistemik memadukan antara dunia akademis dan riset dengan dunia pembangunan melalui pemberdayaan masyarakat. Melalui penyelenggaraan KKN yang terintegrasi dengan pembangunan desa, diharapkan dapat dilakukan integrasi penyelenggaraan program Kuliah Kerja Nyata ke dalam perencanaan desa dengan penekanan pada pendekatan proses pembangunan desa. Integrasi ini dapat dilakukan baik pada tahap perencanaan, pelaksanaan, maupun pengawasan evaluasi pembangunan desa dengan mendorong terjadinya proses yang partisipatif dan inklusif. Titik berat KKN terintegrasi dengan pembangunan desa adalah menumbuhkan kepeloporan mahasiswa dalam rangka mengakselerasi pembangunan desa. Jiwa kepeloporan dalam pembangunan desa akan tumbuh pada diri mahasiswa melalui pemahamannya akan keadaan desa dan ikut berpartisipasi di dalamnya. Kepeloporan mahasiswa bermanfaat bagi pembangunan desa. Adanya pemahaman mengenai pembangunan desa pada generasi muda akan meningkatkan kontribusi mereka dalam mengakselerasi pembangunan desa, Sebaliknya mahasiswa pelopor berpengaruh langsung pada dinamisasi kehidupan masyarakat desa melalui interaksi yang dibangun baik pada saat perencanaan, pelaksanaan maupun pengawasan dalam pembangunan desa selama mereka ditempatkan di desa.

Aparat desa hendaknya lebih mensosialisasikan programnya secara transparan kepada seluruh warga rnayarakat, dan dapat berkoordinasi secara bijaksana dengan cara mengajak anggota mayarakat secara bersarna mangadakan rapat desa dan mau menampung seluruh ide atau gagasan yang diberikan oleh masyarakat, karena bagirnanapun juga anggota masyarakat adalah objek dan subjek pembangunan, sebagai asset berharga tentunya aparat desa harus lebih baik dalam memanejemen pembangunan dengan memanfaatkan potensi yang ada di desa secara maksimal agar pembangunan dapat segera terealisasi sebagaimana rencana.

Untuk aparat desa dan lembaga pembangunan desa, hendaknya dapat menjalankan amanah yang telah diberikan oleh masyarakat, dengan menjalankan proyek pembangunan 
tersebut dengan baik sesuai dengan yang diharapkan, pengawasan dan semua pihak perlu dilakukan untuk menghindari penyimpangan, tetapi rnayarakat harus tetap menjaga hubungan baik dengan para aparat tersebut, dengan membuang rasa curiga yang berlebihan. Warga masyarakat diharapl:an dapat bekerjasarna dengan pemerintah desa dalarn melakukan pembangunan, karena bagaimanapun juga hasil pembangunan akan dirasakan dan digunakan secara bersama, jadi semua warga masyarakat pun mempunyai tanggungjawab dalam pembangunan tersebut.

\section{DAFTAR RUJUKAN}

Agustin, M., \& Rahaju, T. (2016). Partisipasi Masyarakat Dalam Perencanaan Pembangunan Desa Melalui Musrenbang (Studi Kasus Pada Pembangunan Japordes Desa Tunggunjagir Kecamatan Mantup Kabupaten Lamongan). Publika, 4(1), 1-14. https://jurnalmahasiswa.unesa.ac.id/index.php/publika/article/view/13950

Danial, A., Darusman, Y., Mustakim, \& Herwina, W. (2019). Model Pemberdayaan Masyarakat Melalui Pola Magang Tradisional Dalam Upaya Peningkatan Wirausaha Masyarakat. Jurnal Inovasi Hasil Pengabdian Masyarakat (JIPEMAS), 2(1), 31-48. https://doi.org/10.33474/jipemas.v2i1.2182

Dewi, S. P. (2020). Analisis Implementasi Kerjasama Sister-Province Antara Provinsi Yogyakarta dengan Gyeongsangbuk-Do Dalam Pengembangan Desa. Jurnal Inovasi $\begin{array}{lllll}\text { Ilmu Sosial Dan Politik (JSoP), } & \text { 2(1), }\end{array}$ https://doi.org/10.33474/jisop.v2i1.5033

Eko, S. (2014). Desa Membangun Indonesia. Forum Pengembangan Pembaharuan Desa (FPPD).

Fadil, F. (2013). Partisipasi Masyarakat Dalam Musyawarah Perencanaan Pembangunan di Kelurahan Kotabaru Tengah. Jurnal Ilmu Politik Dan Pemerintahan Lokal, 2(2), 251262. https://ppjp.ulm.ac.id/journal/index.php/JIPPL/article/view/897

Fahmie, A. (2001). Analisis Permasalahan Pengambilan Bantuan Modal Kerja Bergulir Dengan Metode ZOPP: Studi Kasus di BKM Berkah Mulyo, Yogyakarta. Psikologika, 12(6), 63-83. 10.20885/psikologika.vol6.iss12.art6

Hardianti, S., Muhammad, H., \& Lutfi, M. (2017). Partisipasi Masyarakat Dalam Pembangunan Infrastruktur Desa (Program Alokasi Dana Desa di Desa Buntongi Kecamatan Ampana Kota). Urnal Katalogis, 5(1), 120-126. http://jurnal.untad.ac.id/jurnal/index.php/Katalogis/article/view/7961

Imtihan, H., Wahyunadi, \& Firmansyah, M. (2017). Peran Pemerintah dan Partisipasi Masyarakat Dalam Perencanaan Pembangunan Daerah (Musrenbang Ds. Taman Sari Kecamatan Gunungsari Kabupaten Lombok Barat 2016). Neo-Bis, 11(1), 28-40. https://doi.org/10.21107/nbs.v1i1.2952

Kader, A., \& Radjak, D. A. (2020). Pembangunan Ekonomi Masyarakat Melalui Agrowisata. Jurnal Inovasi Ilmu Sosial Dan Politik (JISoP), 2(1), 67-79. https://doi.org/10.33474/jisop.v2i1.4997

Laily, E. I. N. (2015). Partisipasi Masyarakat Dalam Perencanaan Pembangunan Partisipatif. Jurnal Kebijakan Dan Manajemen Publik, 3(3), 299-303. http://journal.unair.ac.id/KMP@partisipasi-masyarakat-dalam-perencanaanpembangunan-partisipatif-article-9062-media-138-category-8.html

Maripah, \& Sujianto. (2017). Perencanaan Pembangunan Partisipatif Dalam Penyusunan Rencana Pembangunan Jangka Menengah Desa (RPJMDES) di Desa Pangkalan Baru Kecamatan Siak Hulu Kabupaten Kampar. JOM FISIP, 4(2), 1-15. https://jom.unri.ac.id/index.php/JOMFSIP/article/view/15651

Martino, Y. A., Sulistiowati, E., \& Purnomo, Y. (2018). Model Pemberdayaan Santri Ponpes 
Al-Hidayah Batu Alang Sebagai Kader Kesehatan Berbasis Terapi Herbal. Jurnal Inovasi Hasil Pengabdian Masyarakat (JIPEMAS), 1(2), 86-93. https://doi.org/10.33474/jipemas.v1i2.1514

Ratnadila, N. S. (2018). Perencanaan Skenario untuk Pembangunan Desa Tertinggal: Sebuah Telaah Kritis. Jurnal Penyuluhan Perikanan Dan Kelautan, 12(2), 111-128. https://doi.org/10.33378/jppik.v12i2.104

Sigalingging, A. H., \& Warjio, W. (2014). Partisipasi Masyarakat Dalam Perencanaan Pembangunan (Studi Kasus Pada Kecamatan Sidikalang Kabupaten Dairi). Jurnal Administrasi Publik (Public Administration Journal), 2(2), 116-145. https://ojs.uma.ac.id/index.php/adminpublik/article/view/1383

Susetiawan, Mulyono, D., \& Roniardian, M. Y. (2018). Penguatan Peran Warga Masyarakat dalam Perencanaan, Penganggaran, dan Evaluasi Hasil Pembangunan Desa. Jurnal Pengabdian Kepada Masyarakat (Indonesian Journal of Community Engagement), 4(1), 109-118. https://doi.org/10.22146/jpkm.27512

Syardiansah. (2019). Peranan Kuliah Kerja Nyata Sebagai Bagian Dari Pengembangan Kompetensi Mahasiswa (Studi Kasus Mahasiswa Universitas Samudra KKN Tahun 2017). Jurnal Ilmiah Manajemen UPB, 7(1), 57-68. https://doi.org/10.33884/jimupb.v7i1.915

Ulum, M. C., \& Ngindana, R. (2017). Environmental Governance: Isu Kebijakan dan Tata Kelola Lingkungan Hidup. UB Press.

Warsilan, \& Noor, A. (2015). Peranan Infrastruktur terhadap Pertumbuhan Ekonomi dan Implikasi pada Kebijakan Pembangunan di Kota Samarinda. MIMBAR, Jurnal Sosial Dan Pembangunan, 31(2), 359-366. https://doi.org/10.29313/mimbar.v31i2.1444 